\title{
AKTUALISASI PERAN IBU SEBAGAI MADRASAH PERTAMA DAN UTAMA BAGI ANAK DI ERA 4.0
}

\author{
Muhamad Parhan'1), Dara Puspita Dewi Kurniawan²) \\ Departemen Pendidikan Umum, Fakultas Pendidikan Ilmu Pengetahuan Sosial \\ Universitas Pendidikan Indonesia ${ }^{1}$ \\ Pendidikan Guru Sekolah Dasar, Fakultas Ilmu Pendidikan, Universitas Pendidikan Indonesia ${ }^{2}$ \\ E-mail: parhan.muhamad@upi.edu1, darapuspita122@upi.edu²
}

Submit: 12 Juni 2020, Revisi: 24 Juli 2020, Approve: 12 November 2020

\begin{abstract}
The figure of a mother has an important role for the growth and development of children. Mothers as first and foremost madrasa who always accompany children certainly have to understand the factual conditions in the current era. As we know that in the 4.0 era digital technology progressed rapidly. This is very influential in various aspects of human life. It is undeniable that the progress of digital technology also affects children's development. Therefore, we aim to further examine the actualization of the role of mothers as the first and primary madrasa for children in the 4.0 era. The approach that researchers use is qualitativequantitative (mix method). Research instrument by distributing questionnaire questionnaires as primary data to 53 respondents in the city of Bandung and surrounding areas. Data analysis uses concurrent triangulation designs. The results showed that respondents actually knew the impact of the industrial revolution 4.0 era for children, and agreed to have direction in terms of life goals, controlling the use of digital media, and explaining to children the meaning of positive freedom in era 4.0, by strengthening it through a spiritual attitude approach, instilling good attitudes and habits, responsibilities, foster self-confidence, discipline and independence, all of which start from the family environment through the mother's role as the first and foremost madrasa.
\end{abstract}

Keywords: Actualization; Mother's Role; Era 4.0

Pengutipan: Muhamad Parhan \& Dara Puspita Dewi Kurniawan. (2020). Aktualisasi Peran Ibu Sebagai Madrasah Pertama dan Utama Bagi Anak di Era 4.0. JMIE: Journal of Madrasah Ibtidaiyah Education,4(2), 2019, 157-174. jmie.v4i2.193.

Permalink/DOI: http:/ /dx.doi.org/10.32934/jmie.v4i2.193 


\section{PENDAHULUAN}

Anak adalah aset berharga yang dimiliki oleh orang tua. Anak seperti mutiara yang tidak dapat dinilai harganya. Kehadiran seorang anak memberikan warna baru dan kehidupan baru pada setiap keluarga. Menurut seorang ahli filosofi John Locke mengenai tabula rasa bahwa anak yang baru lahir di dunia diibaratkan seperti kertas putih yang masih kosong (a blank sheet of paper)(Sudirjo, 2016). Oleh karena itu anak dapat dibentuk oleh orang tua akan bagaimana masa depannya sesuai dengan pola pendidikan yang diberikan. Dimulai dari keluarga, lingkungan yang dekat dengan anak. Keluarga yang terdiri dari ayah, ibu, dan anak. Dari sinilah pendidikan pertama yang akan anak dapatkan. Fondasi-fondasi yang kokoh diciptakan agar anak memiliki keyakinan yang kuat untuk menapaki kehidupan yang lebih berat kedepannya di masyarakat. Terlihat peran orang tua, ayah dan ibu dalam mendidik. Seorang ayah sebagai kepala keluarga juga turut andil dalam mendidik anak dimulai saat anak dilahirkan di dunia, seorang ayah mengadzani ditelinga sebelah kanan dan mengqamatinya di sebelah kiri, merawat, memberi nama yang baik, mengakikahkan, dan mendidik anak yang soleh-solehah. Tidak kalah penting seorang ibu sebagai madarasah pertama dan utama bagi anak (madrasab al-ula) sebelum pendidikan-pendidikan formal lainnya. Sesuai dengan "al-ummu madrasah al-ula, idza a'dadtaha a'dadta sya'ban tayyiban al-a'raq." Artinya ibu adalah sekolah pertama, bila engkau mempersiapkannya, maka engkau telah mempersiapkan generasi yang terbaik (Nurhayati \& Syahrizal, 2015). Di dalam Al-Quran peran seorang ayah tidak hanya mencari nafkah dan berkerja saja tetapi memberikan pendidikan nilai-nilai dan moral, sedangkan seorang ibu mengenai pengasuhan (Zarman, 2011).

Sudah bukan rahasia lagi dibalik anak yang hebat terdapat ibu yang hebat. Seorang ibu yang mengajarkan anak dari dalam kandungan selanjutnya masa anak-anak dididik tentang kebiasaan-kebiasaan seperti doa sebelum makan, mengenalkan agama jika islam mengenai iman dan penciptanya, mengajarkan ketika anak mulai haid atau mimpi basah. Dibalik itu semua seorang ibu harus memiliki ilmu yang cukup supaya jawaban yang diberikan tidak sekedar kuantitas belaka tetapi kualitas yang baik. Sebelum ibu mendidik seorang anak, adanya sifat-sifat yang perlu diperhatikan agar anak dapat mencotohnya: 1) Perilaku seorang ibu, 2) Penggunaan bahasa, 3) Pemilihan cerita-cerita, 4) Pemilihan hiburan (Gade, 2012). Sedangkan menurut Ulwan dalam Hartini (2011) mengemukakan bahwa yang perlu diberikan kepada anak dalam proses mendidik yaitu: 1) Akidah, 2) Spiritual, 3) Aturan-aturan, 4) Sosialisasi, dan 5) Kesehatan.

Sebagian orang mengatakan bahwa seorang ibu adalah pendidik bangsa, sebagai contoh dan tauladan adalah Siti Khadijah istri Rasulullah yang dikenal sebagai ummu mukminin (ibu orang-orang mukmin). Sungguh mulia dan anggunnya seorang wanita yang dipanggil ibu. Sebagai seorang muslim dalam mendidik generasi penerus bangsa yang tangguh dibutuhkan 
kompetensi atau kunci yang harus dimiliki seperti, iman, taqwa, tawakal, ikhlas, ilmu dan pengalaman.

Dalam mendidik anak perlu pendidikan yang berkembang sesuai zamannya, seperti hadits yang sangat terkenal dari Ali bin Abi Thalib RA, diriwayatkan bahwa "didiklah anakmu sesuai dengan zamannya, karena mereka bidup bukan dizamanmu” (Mastiyah, 2017). Era atau zaman yang sekarang sedang berlangsung adalah era revolusi industri 4.0 dimana dunia "digital" kini semakin dekat dengan kehidupan kita. Perkembangan teknologi sekarang semakin pesat yang menjadikan semuanya serba digital, sehingga secara langsung maupun tidak langsung perkembangan teknologi dapat mempengaruhi terhadap gaya hidup (Nahriyah, 2017) Sejalan dengan hal tersebut, masuknya pengaruh digital juga berpengaruh besar pada perkembangan anak. Dekatnya pengaruh digital dengan kehidupan kita memberikan berbagai dampak positif dan negatif, hal itu bergantung pada sikap kita menanggapi dan memfilter pengaruh-pengaruh tersebut. Lalu yang menjadi pertanyaan besar ialah "bagaimana kita mendidik anak kita sesuai dengan perkembangan zaman saat ini, di era yang serba digital 4.0?" "Dan apakah ibu sebagai madrasah keluarga dapat mendidik anak dalam era 4.0 sekarang ini?".

Melihat keadaan sekarang ini banyak ibu dalam mendidik anak mereka tidak melihat kondisi era digital. Naisbitt dalam buku (Zarman, 2011) menyebutkan bahwa kita tengah memasuki mabuk teknologi. Mabuk teknologi maksudnya adalah penggunaan teknologi hanya digunakan sebagai mainan saja. Banyak ibu dan orang tua membebaskan anaknya menggunakan teknologi/media digital (Youtube, sosial media dan game) padahal banyak sekali dampak negatif penggunaan media digital bagi anak. Mereka beranggapan bahwa penggunaan media digital saat ini sangat perlu tapi seharusnya ibu mengawasi dan mengontrol penggunaan media digital dengan bijak. Oleh sebab itu, banyak ibu yang tidak siap dengan keadaan era digital. Bahkan menurut Anies Baswedan dalam jurnal (Rahmat, 2018) dibandingkan dengan profesi-profesi lain, orang tua adalah profesi yang paling tidak tersiapkan (Kemendikbud, 2016).

Artinya bahwa menjadi orang tua tidak melalui suatu proses persiapan yang formal atau paling tidak tersiapkan, karena tidak ada sekolah khusus untuk mendidik atau menjadi orang tua. Sedangkan tugas ibu pada era 4.0 sangat banyak, yaitu: 1) Harus mengarahkan citacita atau keinginan anak dengan jelas; 2) Mengarahkan tujuan hidup anak; 3) Menjelaskan arti kebebasan secara positif; 4) Menumbuhkan rasa percaya diri; 5) Mengontrol anak dalam penggunaan media digital; 6) Memberikan pujian agar meningkatkan rasa percaya diri anak; dan 7) Membimbing anak dalam penggunaan media digital ke arah yang positif. Namun kini anak-anak harus mampu tumbuh sendiri tanpa perhatian penuh ibunya. Karena maraknya ibu yang bekerja dan acuh kepada anaknya sendiri. Padahal Allah telah mengamanatkan kewajibannya sebagai seorang ibu bagi anak-anaknya. Sehingga dalam hal ini peneliti perlu mengaktualisasikan lagi peran ibu sebagai madrasah pertama dan utama bagi anak di era 4.0. 


\section{METODE PENELITIAN}

Pendekatan yang digunakan dalam penelitian ini adalah pendekatan kualitatif dan kuantitatif (mix methode) yang mengkombinasikan penelitian kualitatif dan penelitian kuantitatif (Creswell, 2010, hlm. 5). Pendekatan kuantitatif digunakan untuk menghitung dan menganalisis kuesioner berupa angket yang sudah tersebar secara online, disajikan dalam bentuk angka-angka dan diagram. Pendekatan kualitatif digunakan untuk mendeskripsikan data-data yang sudah didapatkan dan dihasilkan dalam perhitungan kuantitatif. Kemudian disusun sebuah narasi yang dituangkan dalam bentuk tulisan (naratif) untuk ditafsirkan dan dianalisis terkait peran ibu sebagai madrasah pertama dan utama dalam era 4.0.

Data penelitian diperoleh dari dua sumber yaitu sumber primer dan sumber sekunder. Sumber primer adalah sumber yang digunakan dalam penelitian, yaitu ibu-ibu yang memiliki anak dari usia 0-12 tahun sebanyak 53 responden, yang dilakukan di wilayah Kota Bandung dan sekitarnya. Sedangkan data sekunder adalah data yang melengkapi data primer yaitu teori-teori yang dihasilkan dari penelitian sebelumnya dan tokoh-tokoh ahli. Teknik pengumpulan data yang digunakan dengan menggunakan studi literatur atau studi pustaka dan kuesioner berupa angket secara online melalui google form. Studi literatur bertujuan untuk mencari sebuah teori dan konsep yang digunakan sebagai pedoman dan fondasi dalam penelitian peran ibu sebagai madrasah pertama dan utama di era 4.0. Studi literatur dari berbagai sumber dan jurnal yang sudah terverifikasi. Pada Teknik kuesioner berupa angket online (google form) untuk melihat secara detail data di lapangan. Angket online dalam bentuk google form, sehingga dapat menjangkau responden yang banyak dengan cara membagikan link angket tersebut melalui media sosial.

Analisis data yang dilakukan adalah concurrent triangulation designs atau design integrantive atau konvergen, dimana peneliti secara bersamaan mengumpulkan data kualitatif dan kuantitatif, kemudian menafsirkan hasilnya bersama-sama dalam menyajikan pemahaman yang lebih baik melalui fenomena yang ditemukan. Data yang sudah dikumpulkan dikelompokan sesuai sub bahasan masing-masing, dilanjutkan dengan menganalisis jawaban yang diberikan oleh responden dengan teori yang relevan, kemudian dilanjutkan dengan menarik sebuah kesimpulan.

\section{HASIL PENELITIAN DAN PEMBAHASAN}

\section{Peran Ibu Sebagai Madrasah Pertama dan Utama}

Setiap ibu memiliki cara mendidiknya masing-masing. Faktor yang menyebabkan salah satunya karena ilmu, pengalaman, pekerjaan, dan usia. Dalam penelitian yang telah dilakukan, dengan jumlah 53 responden diketahui bahwa usia yang dimiliki yaitu random atau 
acak, dengan responden terbanyak berada pada rentan usia 33-38 tahun. Hal itu dapat dilihat dari diagram di bawah ini:

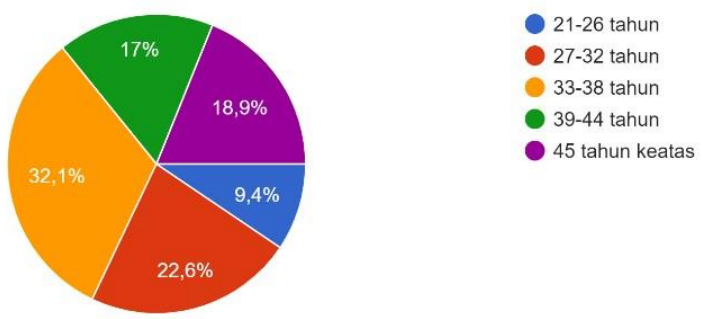

\section{Gambar 1. Hasil angket usia responden}

Jika dilihat dalam segi pekerjaan, responden terdiri dari ibu rumah tangga, pegawai swata/negeri, wirausaha, honorer, dan kader PKK. Dengan hasil pekerjaan terbanyak sebagi ibu rumah tangga. Hal itu dapat dilihat dari diagram di bawah ini:
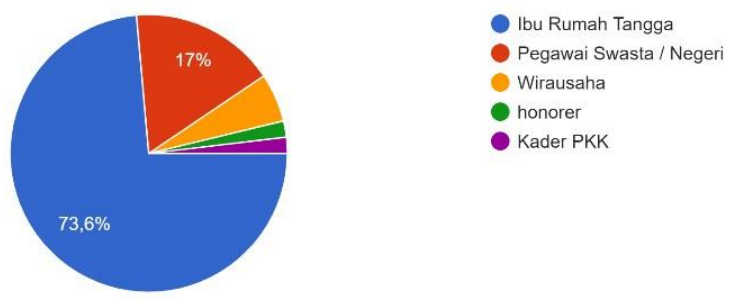

\section{Gambar 2. Hasil angket pekerjaan ibu}

Berhubungan dengan usia terbanyak di 33-38 tahun, sesuai dengan hasil pendidikan anak terbanyak pada pendidikan SD, dapat dilihat dari diagram di bawah ini:

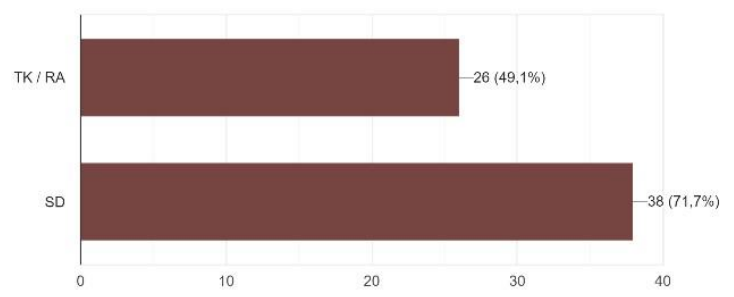

Gambar 3. Hasil angket pendidikan anak TK/RA dan SD

Dapat dikatakan sebagai seorang ibu ketika Allah Swt menitipkan seorang janin di dalam perut seorang wanita. Perasaan saat mengetahui tentang kehamilan, respon yang diberikan berbeda-beda pada setiap ibu. Perasaan bahagia, cemas, sedih, dan malu. Dari 
responden yang telah mengisi perasaan ibu ketika mendengar dirinya hamil adalah bahagia, cemas, dan sedih, sejalan dengan hal itu Martalisa dan Budisetyani (2013) mengungkapkan bahwa seorang ibu ketika hamil dihinggapi campuran perasaan, ada takut, berani, lemah hati, ngeri, cinta, benci, ragu, kegelisahan, tenang, bahagia, harapan dan penuh kegembiraan. Tetapi responden menjatuhkan pilihan terbanyak pada perasaan bahagia. Seorang ibu mana yang tidak merasa bahagia saat Allah Swt memberikan amanah seorang anak pada dirinya. Hal itu dapat dilihat dari diagram di bawah ini:

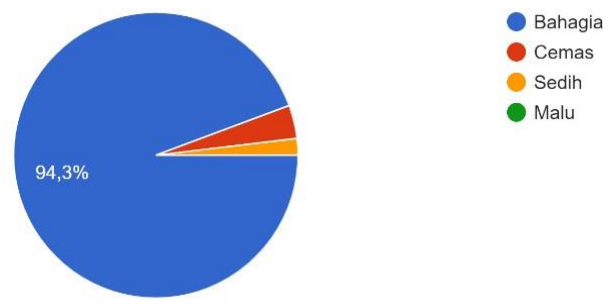

\section{Gambar 4. Hasil angket perasaan seorang ibu saat mengetahui dirinya hamil}

Proses pendidikan yang diberikan pada keluarga dimulai dari proses pengasuhan dan keterlibatan orang tua kepada anak. Sesuai dengan hasil penelitian, di Kota Bandung proses pengasuhan masih dilakukan oleh orang tua sendiri secara langsung terutama oleh ibu, walaupun banyak asumsi yang mengatakan perempuan di Kota Bandung banyak yang bekerja di luar, tetapi masih banyak yang mengurus rumah tangga sendiri, hal ini sesuai dengan data BPS Provinsi Jawa Barat (BPS Provinsi Jawa Barat, 2018). Peran ibu sebagai madarasah al-ula dalam mendidik anak, pada hakikatnya tidak bisa digantikan oleh siapapun. Mungkin pengasuh maupun orang lain selain ibu dapat mengasuh, tetapi pengasuhannya hanya bersifat mengajarkan saja, mengenai masalah kasih sayang itu hanya dapat diberikan oleh seorang ibu. Karena seorang anak apalagi yang masih dalam tahap balita dan anak-anak dalam pengasuhan dan pengajarannya masih harus dibumbui dengan rasa kasih sayang yang penuh. Dalam mendidik anak seorang ibu juga menggunakan sentuhan kasih sayang secara fisik maupun psikisnya, tetapi jika pendidikan yang menjadi tanggung jawab seorang ibu digantikan oleh orang lain, pastinya akan memunculkan sebuah masalah terhadap anak itu sendiri. Hal itu sesuai dengan temuan di lapangan dapat dilihat pada diagram di bawah ini:

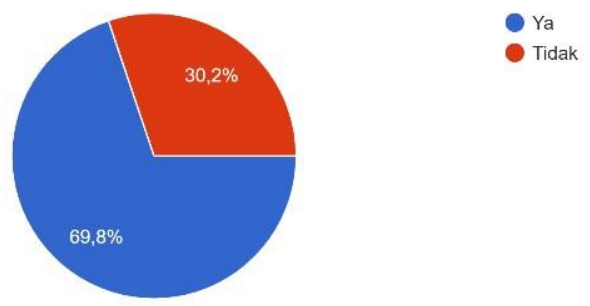

Gambar 5. Hasil angket pengasuhan yang diberikan kepada anak 
Layaknya melaksanakan sebuah kegiatan, proses pendidikan memerlukan sebuah perencanaan yang matang, sebelum dilaksanakan adanya tindakan. Pendidikan yang dilaksanakan didalam keluarga yang dilangsungkan oleh seorang ibu, perlu adanya sebuah perencanaan, tindakan, dan evaluasi. Sesuai dengan jurnal itqan, dalam tahap perencanaan, seorang ibu mempersiapkan secara rohaniah dan batiniah, seperti ilmu dalam mendidik. Sehingga peran seorang ibu dapat menjadi pedoman dalam menuntun nilai-nilai kebaikan bagi anaknya (Parhan, dkk. 2020) .

Ilmu yang harus dipersiapkan seperti syariat-syariat dalam islam, akidah, norma-norma dalam agama dan sosial yang bertujuan untuk mempersiapkan anak di masa depan (Nurhayati \& Syahrizal, 2015). Sesuai dengan temuan di lapangan ibu di Kota Bandung, sudah mempersiapkan dengan cara mengikuti latihan atau kursus dan belajar secara mandiri melalui media daring, seperti dapat dilihat pada diagram di bawah ini:
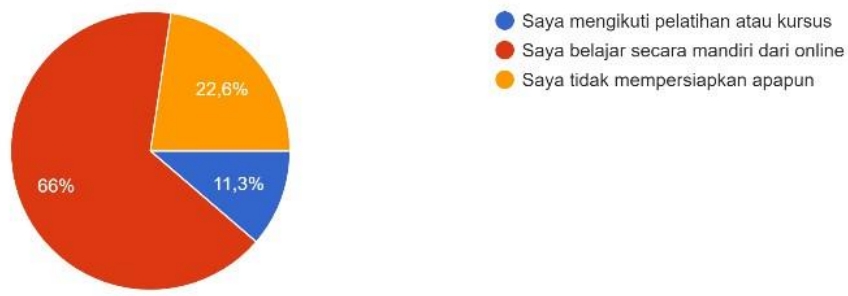

Saya mengikuti pelatihan atau kursus

Saya belajar secara mandiri dari online

Saya tidak mempersiapkan apapun

\section{Gambar 6. Hasil angket persiapan ibu dalam mendidik anak}

Proses pendidikan yang diberikan kepada anak sudah dimulai dari dalam kandungan, pada usia janin menginjak tiga bulan, janin sudah mulai memiliki ukuran yang sempurna tidak lagi berbentuk embrio, sudah dapat melakukan gerakan-gerakan seperti memutar telapak kaki, mengerutkan dahi, dan merentangkan jari. Namun gerakan-gerakan ini belum dapat dirasakan secara sepenuhnya oleh si ibu. Mulai memasuki bulan keempat dan kelima, secara fisik sudah tumbuh alis, bulu mata, rambut kepala, detak jantung sudah dapat dirasakan oleh si ibu, sehingga dalam pemeriksaan kandungan dapat menggunakan stetoskop. Gerakan-gerakan bayi sudah mulai dapat dirasakan oleh si ibu dengan adanya tendangan-tendangan dalam merespon saat berkomunikasi. Dikarenakan otot-otot sudah mulai kuat dan berfungsi. Sehingga pendidikan anak dalam kandungan tentu penting, karena pendidikan ini adalah dasar dimulainya pendidikan. Pendidikan yang dilakukan dapat berupa komunikasi orang tua kepada calon bayi, memperdengarkan ayat-ayat suci Al-Quran, ibu melakukan kebiasaan-kebiasaan yang baik, dan pemenuhan nutrisi yang cukup (Subakti \& Anggrani 2007). Hasil temuan di lapangan menunjukan bahwa pendidikan yang dilakukan oleh seorang ibu kepada anak dalam kandungan sudah tepat dengan cara mendengarkan ayat-ayat suci Al-quran dan mengajak bicara calon bayi. Walaupun dalam rasio yang sangat 
kecil, masih terdapat ibu yang tidak memberikan treatment apapun ketika bayi di dalam kandungan. Hal ini dapat dilihat seperti dalam diagram di bawah ini:
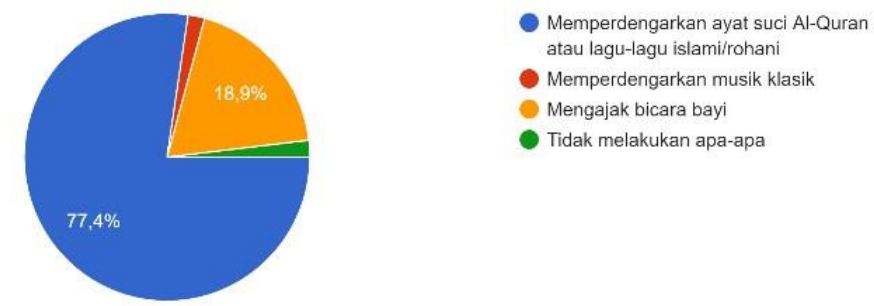

\section{Gambar 7. Hasil angket pendidikan atau kebiasaan ibu kepada calon bayi saat di dalam kandungan.}

Pada anak usia 0-5 tahun, anak berada pada balita. Pembelajaran dapat dilaksanakan secara formal yaitu pada pendidikan PAUD dan TK. Pendidikan dalam keluarga memiliki peran yang penting dalam usia-usia balita. Karena dalam tahap ini, anak menjadi peniru yang baik dari perilaku yang dilakukan oleh orang dewasa. Sehingga perlu adanya kehati-hatian dalam memberikan pembiasan dan contoh kepada anak. Dalam usia ini, seorang ibu memberikan pendidikan secara dasar dan fondasi-fondasi yang kuat. Pendidikan yang diberikan sesuai dengan perkembangan anak balita seperti: 1) Menanamkan sikap spiritual, dengan kegiatan-kegiatan yang dilakukan secara sederhana (berdoa sebelum makan, doa harian, rukun iman, rukun islam, cerita-cerita mengenai Nabi dan Rasul), 2) Tidak memanjakan anak (menuruti semua kemauan anak), 3) menjadi suri tauladan yang baik, 4) Mengajari berjalan dengan perlahan dan belajar berbicara dengan kata-kata yang baik, 5) Mencari mainan atau hiburan yang dapat merangsang daya kreatif anak, 6) Tidak bersikap keras kepada anak sampai melukai fisik dan psikologisnya, 7) Berkomunikasi secara teratur dan intens dengan anak, meluangkan waktu untuk berbincang-bincang, 8) Mulai untuk memberikan tanggung jawab secara secara sederhana dengan membereskan mainan, menyiapkan buku-buku yang akan di gunakan saat disekolah, mengerjakan tugas rumah dengan dibantu oleh orang tua. (Mahrus, 2018). Jika dilihat di lapangan, di Kota Bandung orang tua terurama ibu sudah melaksanakan pendidikan kepada anaknya pada usia balita sesuai dengan teori, yaitu mengajarkan sikap spiritual, mengajarkan berbicara, berjalan, pendidikan formal PAUD, TK, dan TPA, menanamkan sikap dan kebiasan yang baik (disiplin dan mandiri).

Pada rentan usia 6-12 tahun, anak sudah memasuki tahap sekolah formal ke jenjang yang lebih tinggi yaitu sekolah dasar. Pendidikan yang diberikan lebih tinggi jenjangnya daripada usia balita (0-5 tahun). Pada usia ini pendidikan yang diajarkan, yaitu: 1) Penanaman sikap spiritual, 2) Memberikan tanggung jawab sesuai porsi perkembangannya, 3) Ketika menonton TV anak tetap ditemani oleh orang tua, 4) Mengenalkan sikap-sikap silaturahmi kepada kerabat-kerabat terdekat, 5) Mengenalkan dan menanamkan sikap-sikap sebagai warga 
negara yang baik, 6) Memasukkan di sekolah formal yang lebih tinggi jenjangnya yaitu sekolah dasar. (Mahrus, 2018). Data lapangan yang didapatkan oleh peneliti, menjelaskan bahwa ibu dalam mendidik anak pada usia 6-12 tahun, memberikan pendidikan spiritual, akhlak, tanggung jawab, kedisiplinan, belajar calistung, kemandirian. Hal ini sudah sesuai dengan teori pendidikan anak di usia 6-12 tahun.

\section{Pengaruh Revolusi Industri 4.0 Terhadap Perkembangan Anak}

Di era sekarang ini, penyebarluasan infomasi menggunakan teknologi digital kian cepat dan fleksibel. Bisa dikatakan bahwa era digital merupakan dunia serba gadget dan internet. Zaman sudah berubah, kita berbeda zaman dan berbeda generasi dengan anak-anak kita. Sering kita melihat anak berumur dua tahun sudah fasih sekali mengoperasikan youtube, sedangkan kita sendiri kadang kesulitan (Sukiman, 2016).

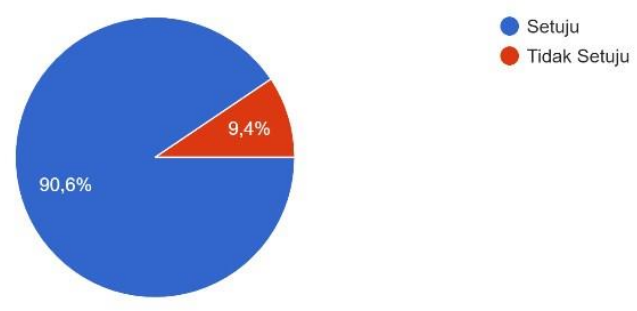

\section{Gambar 8: Grafik masuknya pengaruh digital berdampak bagi perkembangan anak.}

Dapat terlihat pada grafik bahwa $90.8 \%$ responden setuju bahwa masuknya pengaruh digital berdampak bagi perkembangan anak. Sedangkan hanya 9.4\% responden yang tidak sependapat dengan pernyataan tersebut. Hal ini sejalan dengan pendapat Nahriyah bahwa perkembangan teknologi sekarang semakin pesat yang menjadikan semuanya serba digital, sehingga secara langsung maupun tidak langsung perkembangan teknologi dapat mempengaruhi terhadap gaya hidup (Nahriyah, 2017). Penggunaan media digital dalam kehidupan sehari-hari dapat meningkatkan efektifitas pekerjaan manusia. Sejalan dengan pendapat tersebut, media digital sangat mempengaruhi perkembangan anak, karena disadari atau tidak teknologi digital berpengaruh besar dalam tumbuh kembang anak.

Belajar bukan sekedar aktivitas kognitif saja, melainkan juga sebuah proses yang terjadi dalam diri individu yang melibatkan seluruh bagian atau domain yang ada, seperti emosi atau perasaan, komunikasi yang terbuka dan nilai-nilai yang dimiliki oleh setiap peserta didik (Parhan \& Sutedja, 2019). Perkembangan teknologi digital di era 4.0 memegang peranan besar dalam proses belajar anak. Tersedianya berbagai fasilitas untuk menunjang pembelajaran diharapkan dapat berbanding lurus dengan hasil belajar siswa. 
Teknologi digital atau gadget itu sendiri pada dasarnya bersifat netral. Seperti halnya dua mata pisau, gadget bisa bermanfaat bisa juga berbahaya. Yang menentukan pisau itu berbahaya atau bermanfaat adalah penggunanya (Sukiman, 2016). Dalam kuisioner yang kami sebarkan, kami juga meneliti lebih jauh tentang wawasan umum responden tentang dampak positif kehadiran teknologi digital di era 4.0. Dari hasil penyebaran kuisioner dapat kami simpulkan bahwa semua responden "ibu" sudah memiliki wawasan umum tentang dampak positif dari perkembangan teknologi digital. Secara lebih lengkapnya berikut adalah contoh dampak positif dari teknologi digital bagi anak, yaitu : 1) Menjadi sumber informasi, 2) Sarana komunikasi, 3) Pembelajaran jarak jauh, 4) Jejaring sosial, dan 5) Memperkenalkan jenis profesi baru (Sukiman, 2016).

Salah satu pengaruh negatif perkembangan teknologi adalah tidak teraturnya pola makan anak akibat kecanduan gadget. Dalam penyebaran kuisioner yang kami lakukan terkait antisipasi dari pengaruh negatif tersebut mayoritas responden memilih untuk membatasi penggunaan gadget pada anak, responden yang sekaligus berperan sebagai seorang ibu dapat menjadwalkan pemakaian gadget anak, agar anak tidak kecanduan misalkan menjadwalkan pemakaian gadget hanya pada hari libur saja atau hanya dipakai di waktu pulang sekolah hingga pukul 6. Setelah itu anak diminta untuk sholat, makan dan mengerjakan PR yang diberikan guru, serta mempersiapkan kebutuhan sekolahnya besok. Sejalan dengan hasil analisis kuisioner tersebut berikut adalah beberapa dampak negatif dari perkembangan teknologi digital antara lain : 1) Anak lebih banyak menghabiskan waktu menonton TV ketimbang melakukan hal lainnya (seperti belajar dan olah raga), 2) Anak kehilangan kemampuan berbaur dengan masyarakat dan cenderung nyaman dengan kehidupan online, 3) Kejahatan di Internet, 4) Pornografi, perjudian, penipuan, tayangan kekerasan (Ratnaya, 2011).

\section{Tantangan Pendidikan dan Pengasuhan pada Era Digital}

Di samping manfaat di atas, ternyata gadget juga menyimpan berbagai risiko yang jika kita tidak bijaksana menggunakannya, akan berdampak negatif. Berikut ini berbagai potensi risiko yang perlu diperhatikan oleh orang tua, menurut Sukiman (2016) adalah: 1) Kesehatan Mata Anak: Paparan berlebihan terhadap bermain gadget dapat memicu penglihatan yang buruk; 2) Masalah Tidur: Masalah tidur anak yang dapat terjadi karena anak terlalu lama melihat layar digital; 3) Kesulitan Konsentrasi: Penggunaan media digital memiliki efek dapat mengubah perhatian anak sehingga bisa meningkatkan perilaku terlalu aktif dan kesulitan untuk berkonsentrasi; 4) Menurunnya Prestasi Belajar: Penggunaan game dalam gadget yang berlebihan dapat mengganggu anak dalam belajar; 5) Perkembangan Fisik: Karena anak terlalu fokus bermain gadget dan enggan berhenti. Anak cenderung menahan lapar, haus, BAB/BAK, yang dapat memicu ketidakseimbangan berat tubuh; 6) Perkembangan Sosial: Anak cenderung tumbuh dengan mementingkan diri sendiri dan kurang bersosialisasi dengan orang lain; 7) 
Perkembangan Otak dan Hubungannya dengan Penggunaan Media Digital: Anak perlu menyeimbangkan kegiatannya di dunia nyata dan digital; dan 8) Menunda Perkembangan Bahasa Anak: Penelitian menunjukkan bahwa penggunaan media digital berlebih dapat menunda perkembangan bahasa anak. Apalagi jika orang tua membiasakan anak usia balita hanya bermain dengan gadget tanpa menstimulus anak berbicara.

\section{Aktualisasi Peran Ibu Dalam Era 4.0}

Aktualisasi berasal dari kata dasar actual, yang artinya benar-benar ada atau sesungguhnya, sehingga kata aktualiasasi artinya membuat sesuatu benar-benar ada (Rosyad \& Zuchdi, 2018). Sedangkan peran Ibu adalah seorang pendidik yang selalu mengetahui kegiatan dan kesukaan anaknya (Sarafuddin \& Jumanto, 2016). Jadi aktualisasi peran ibu di era 4.0 adalah peran ibu yang benar-benar ada atau dilakukan sesuai dengan era 4.0. Namun arti dari aktualisasi peran ibu di era 4.0 itu seolah hilang dengan realita yang ada di masyarakat. Banyak Ibu yang memilih bekerja atau walaupun sebagai ibu rumah tangga namun mereka tidak menjalankan kewajibannya sebagai seorang ibu. Setiap wanita hendaknya menyadari ketika ia menikah dan dikaruniai anak, maka sejak itu ia telah dibebankan suatu amanat yang harus diitunaikan sebagai pendidik pertama di keluarga yang berusaha untuk mendidik anaknya supaya disadarkan pada harapan yang akan anak capai, tantangan yang akan mereka hadapi, dan kemampuan yang mereka perlu kuasai (Parhan \& Sutedja 2019). Sebab anak yang masih belum tau apa-apa harus di bimbing agar anak tidak mendapatkan pengaruh negatif dari lingkungan sekitarnya. Apalagi dengan masuknya era revolusi industri yang masuk dalam kehidupan masyarakat.

Era yang berubah dan pengetahuan semakin berkembang menciptakan era baru bagi dunia. Dalam jurnal (Abdullah, 2019) memasuki tahun 2018, seluruh sandi kehidupan manusia modern mengalami perubahan cepat. Perubahan cepat tersebut merupakan bagian dari revolusi industri keempat atau kerap ditulis Revolusi Industri 4.0. Kehadiran Revolusi Industri 4.0 berupa peningkatan perkembangan teknologi sangat canggih yang berpengaruh besar terhadap kehidupan manusia seperti kecerdasan buatan (artificial intelligence), perdagangan digital (e-commerce), data raksasa, teknologi finansial, ekonomi berbagi, hingga penggunaan robot (Prasetiantono, 2018). Bahkan pendidikan bagi anak pun berubah dengan adanya era baru ini.

Menurut Naisbitt dalam Zarman (2011) menyebutkan bahwa kita tengah memasuki mabuk teknologi. Mabuk teknologi maksudnya adalah Penggunaan teknologi hanya digunakan sebagai mainan saja. Padahal teknologi tidak sepenuhnya hal yang positif saja tapi ada sisi negatif dalam teknologi. Apalagi anak era sekarang yang sudah melek dengan teknologi. Bila tidak ada pengawasan dari ibu sebagai pendidik pertama di rumah maka hal yang negatif dalam teknologi akan masuk dalam pemahaman anak. Dengan zaman yang telah berubah dan 
masuknya teknologi kepada kehidupan anak maka tugas ibu makin bertambah. Artinya sekarang ini banyak ibu yang belum siap dalam mendidik anak pada era sekarang. Sebagaimana yang ditegaskan oleh Anies Baswedan dalam jurnal (Rahmat, 2018) bahwa dibandingkan dengan profesi-profesi lain, orang tua adalah profesi yang paling tidak tersiapkan (Kemendikbud, 2016). Artinya bahwa menjadi orang tua tidak melalui suatu proses persiapan yang formal atau paling tidak tersiapkan karena tidak ada sekolah khusus untuk mendidik atau menjadi orang tua.

Menurut Santosa, dalam jurnal (Rahmat, 2018) Anak generasi 4.0 memiliki karakteristik sebagai berikut : 1) Anak zaman sekarang cenderung memiliki karakter yang positif dan optimis dalam menggapai mimpi dalam hidupnya. Orang tua dari generasi ini mayoritas lebih mapan, mampu memberikan fasilitas, dan rasa nyaman kepada anak. Anak harus memiliki ambisi atau goal sejak dini. Oleh karena itu, orang tua perlu mendefinisikan goal atau cita-cita anak dengan jelas dan benar; 2) Anak cenderung berpikir praktis dan berperilaku instan (speed). Realitas ini mengharuskan orang tua untuk mendidik anak tentang konsep proses, daya tahan (endurance) dan komitmen untuk menjalankan tugas. Orang tua yang bijak akan membimbing seorang anak untuk menemukan kiat-kiat dan langkah-langkah praktis dalam menemukan tujuan hidup anaknya; 3) Anak mencintai kebebasan. Oleh karena itu, orang tua perlu memberikan penjelasan logis tentang peraturan yang berlaku di rumah. Orang tua perlu memberikan konsep kebebasan yang bertanggung jawab kepada anak-anak; 4) Percaya diri. Orang tua perlu membantu anak supaya sikap optimis dan percaya diri terus bertumbuh dan berkembang dengan baik; 5) Anak cenderung menyukai hal yang detail. Orang tua wajib meng-upgrade diri dengan informasi global terkini mengenai dunia dan tren anak zaman sekarang. Para pendidik dan orang tua perlu lebih maju satu tingkat di atas atau setidaknya setara dengan pengetahuan anak. Dengan itu, orang tua dan pendidik dapat mengontrol perilaku dan aktivitas anak dalam menggunakan media digital; 6) Anak mempunyai keinginan besar untuk mendapatkan pengakuan. Orang tua harus berusaha untuk memberikan reward dalam bentuk hadiah kecil, pujian, pelukan atau katakata yang bersifat memotivasi sebagai bentuk apresiasi atas usaha yang ditunjukkan anak; dan 7) Anak mahir menggunakan digital dan teknologi informasi. Orang tua perlu mengetahui informasi terkini dalam era digital. Orang tua juga tidak boleh memasung anak dalam isolasi lingkungan yang jauh dari teknologi, tetapi mendampingi atau menemani anak supaya dapat memanfaatkan media digital dan teknologi secara baik untuk tujuan-tujuan yang positif. Pendapat Santosa ini membuktikan karakteristik anak 4.0 memiliki tujuan nya sendiri atau mempunyai prinsip masa depan masing-masing, walaupun tujuan nya harus distimulus oleh orang tuanya agar anak mempunyai pemikiran tersebut.

Dari uraian di atas ternyata anak era 4.0 sangat berbeda sehingga pengasuhan dan penanganan bagi anaknya pun berbeda. Oleh sebab itu, dapat kita simpulkan peran ibu dalam era 4.0 sesuai dengan karakteristik anak 4.0 : 1) Harus mengarahkan cita-cita atau 
keinginan anak dengan jelas; 2) Mengarahkan Tujuan hidup anak; 3) Menjelaskan arti kebebasan secara positif; 4) Menumbuhkan rasa percaya diri; 5) Mengontrol anak dalam penggunaan media digital; 6) Memberikan pujian agar meningkatkan rasa percaya diri anak; dan 7) Membimbing anak dalam penggunaan media digital ke arah yang positif

Dengan peran ibu yang sesuai dengan karakteristik anak 4.0 diharapkan ibu bahkan ayah pun dapat menjalankan tugasnya sebagai orang tua dengan baik dan penuh tanggung jawab. Hal ini dilakukan supaya orang tua dapat membimbing dan mengarahkan anak untuk dapat menghadapi tantangan di era 4.0. Karena peran orang tua dapat menginternalisasikan sikap, pikiran dan kepribadian, yang masuk ke alam pikiran anak sehingga menjadi bagian dari dirinya (Kartono, hlm. 236). Sejalan dengan pendapat tersebut, Porwadarminta (2002) menegaskan bahwa pengasuhan merupakan proses internalisasi nilai dari orang tua kepada anaknya dengan menanamkan sebuah keyakinan dan kesadaran akan kebenaran nilai yang ditanamkannya, untuk kemudian diwujudkan dalam sikap dan perilaku.

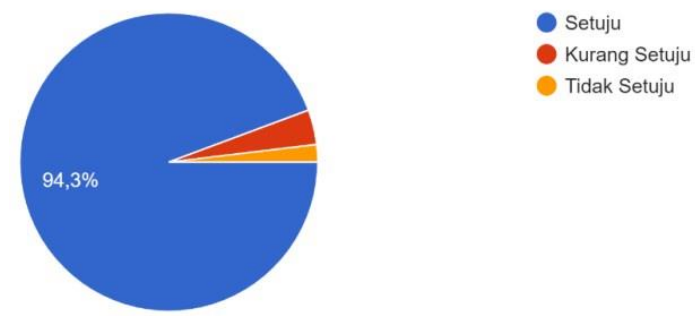

\section{Gambar 9: Grafik pentingnya pengarahan tujuan hidup bagi anak}

Grafik di atas menunjukan bahwa 94,3\% para ibu setuju dengan pentingnya pengarahan tujuan hidup anak maka sejalan dengan pendapat Santosa (2015:20-28), bahwa Anak cenderung berpikir praktis dan berperilaku instan (speed) oleh sebab itu, ibu harus senantiasa untuk mendidik anak tentang konsep proses, daya tahan (endurance), komitmen untuk menjalankan tugas, dan untuk menemukan tujuan hidupnya. Selain itu pengarahan tujuan bagi anak akan menghantarakan anak menuju tahap demi tahap perkembangannya dan memastikan seorang anak dapat melaluinya dengan baik (Trianingsih, 2016).

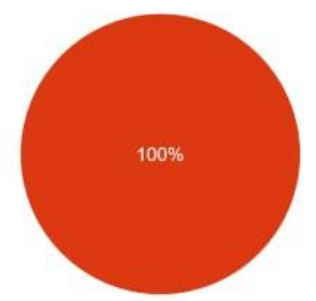

Melarang anak menggunakan media digital

- Siap sedia mengawasi dan menggontrol penggunaan media digital tersebut

Membebaskan anak menggunakan media digital

Gambar 10 : Grafik pernyataan tentang peran ibu dalam mengawasi dan mengontrol anak dalam penggunaan media digital. 
Era yang berubah dan pengetahuan semakin berkembang menciptakan era baru bagi dunia. Dalam jurnal (Abdullah, 2019) memasuki tahun 2018, seluruh sandi kehidupan manusia modern mengalami perubahan cepat. Perubahan cepat tersebut merupakan bagian dari revolusi industri keempat. Era 4.0 dapat menimbulkan efek positif dan juga efek negatif. Dampak positif dari perkembangan era ini adalah kemudahan dalam komunikasi, dan transportasi. Namun, dari beberapa dampak positif tersebut, perkembangan era ini memiliki dampak negatif yang cukup signifikan (Astuti, Farida, \& Faudzan, 2020). Maka mengontrol dan mengawasi dalam penggunaan media digital adalah salah satu tugas bagi ibu karena di era digital 4.0 ini teknologi sangat berpengaruh dalam kehidupan masyarakat. Dilihat dari diagram 100\% setuju dalam mengawasi dan mengontrol penggunaan media digital. Bahkan menurut Santosa (2015:20-28), Anak cenderung menyukai hal yang detail. Maka ibu harus siap mengupgrade pengetahuannya tentang teknologi agar bisa mengetahui mana yang baik dan buruk bagi anaknya.

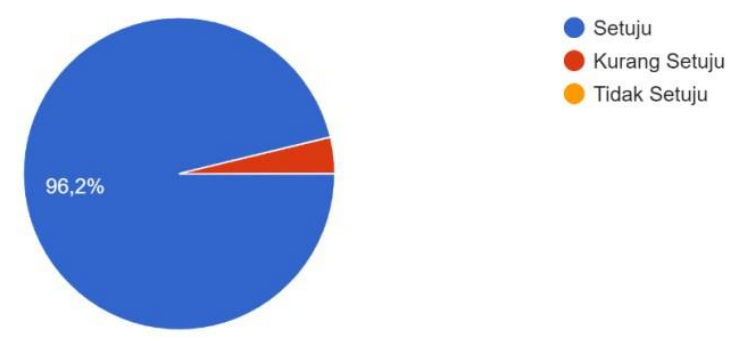

\section{Gambar 11 : Grafik pengarahan arti kebebasan dalam hal postif oleh ibu.}

Menurut Santosa (2015:20-28), Anak mencintai kebebasan. Namun banyak sekali anak yang mensalahartikan tentang kebebasan itu sendiri apalagi bila tanpa ada pengawasan orang tua. Dilihat dari diagram di atas 96,2\% setuju dengan pernyataan bahwa ibu harus menjelaskan terlebih dahulu arti kebebasan dalam arti positif. Maka, fakta yang ada sekarang sejalan dengan teori Santosa tersebut. Namun 3,8 \% ada yang kurang setuju dengan pernyataan di atas. Padahal ibu harus membimbing agar anak bisa mengetahui mana yang baik atau yang buruk baginya.

Dari hasil kuisioner tentang pendapat para ibu dalam meminimalisir dampak negatif dari media digital adalah dengan mengontrol, mendampingi, dan mengawasi kegiatan anak dalam menggunakan media digital. Sejalan dengan pendapat Santosa (2015:20-28), orang tua dan pendidik dapat mengontrol perilaku dan aktivitas anak dalam menggunakan media digital. Sebenarnya penggunaan gadget atau alat-alat digital lainnya pada era ini, tidak dapat dimusnahkan secara seutuhnya atau melarang anak untuk tidak mengenal dan mengoperasikan gadget. Karena hal itu bukan tips dan trik yang tepat.

Sesuai dengan modul mendidik anak di era digital hal yang perlu yang perlu dilakukan oleh orang tua yaitu dengan mengawasi, membatasi, dan mengendalikan 
pengoperasian gadget pada anak dengan cara tips-tips berikut ini: 1) Membuat kesepakatan dengan pasangan, anak, dan diri sendiri, misalnya dengan membuat jadwal penggunaan gadget, apa saja situs yang boleh di jelajah, game apa yang boleh digunakan. Buat kesepakatan di awal, jangan ketika terdapat permasalahan kesepakatan baru di buat, maka itu tidak sukses dan tepat untuk diterapkan. Dengan melakukan negosisasi terlebih dahulu, serta tidak merugikan atau menguntungkan salah satu pihak. 2) Mengajarkan game atau hiburan yang sesuai dengan tahap perkembangan dan cara berfikirnya. Tidak menggunakan game bunuh membunuh saat anak masih usia balita, karena cara berfikir masih menjadi peniru yang baik. 3) Dibuatkan peraturan yang telah disepakati bersama antar diri sendiri, pasangan, dan anak. Misalnya jadwal penggunaan gadget dalam sepekan, durasi penggunaan, 4) Melatih dengan perlahan anak untuk berfikir, memilih, dan memutuskan dengan ranah pengawasan orang tua. Tidak memberikan apapun saat anak menginginkan tetapi berikan sebuah tantangan atau pertanyaan mengenai apapun, 5) Pengkondisian lingkungan, mengkondisikan pasangan, orang tua, mertua, kerabat, saudara yang berada dekat di keluarga. Untuk meminamalisir penggunaan gadget dan memberitahu dengan adanya komitmen di dalam keluarga yang telah disepakati. 6) Buatlah pertanyaan kepada anak "apakah gadget kebutuhan atau hanya mengikuti teman-temannya?" Beritahu resiko-resiko yang akan terjadi jika gadget disalahgunakan. 7) Jangan pernah memberikan ponsel sebagai penghibur dengan alasan supaya anteng atau supaya tidak menangis. Banyak sekali kegiatan yang bisa dilakukan oleh orang tua agar anak nya tidak rewel contohnya bermain puzzle. Bermain puzzle bisa melatih anak dalam hal motorik dan anak akan fokus pada kegiatan puzzle tersebut. 8) Karena teknologi terdapat dampak postif dan negatif nya maka ibu bisa kenalkan terlebih dahulu media digital sesuai kegunaan utamanya. Agar anak tidak menyalahartikan fungsi dari media digital tersebut. 9) Bila ibu belum mampu untuk mengawasi anak dalam penggunaan media digital maka lebih baik orang tua tidak memberikan gadget kepada anak. Karena ibu adalah pendidik pertama anak di keluarga. 10) “Usia anaknya berapa?”. Di atas tiga tahun. Jangan sampai salah melekat. Umur 0-3 tahun adalah Periode Emas Attachment (kelekatan) ketika dopamin sedang terbentuk atau diproduksi. Pada usia ini, seorang anak akan lekat pada apa pun atau siapa pun yang membuatnya senang. Bila anak lekat dengan teknologi maka anak akan candu dalam penggunaan media digital dan akan susah bila lepas dari kecanduan media digital. 11) Beri aktivitas alternatif lain yang lebih menarik atau sama menariknya dengan gadget atau games, misalnya berkemah, mancakrida (outbound), berenang, pergi ke museum. Ajaklah anak untuk bersosialisasi dengan sekitarnya agar anak mampu berkomunikasi dengan baik dan menjadi latihan bagi anak bila bertemu dengan orang baru dia kenal. 12) Buat anak selalu sibuk dengan tanggung jawab, dengan diajarkan prioritas seperti tugas pribadi. Bila tanggung jawab tersebut sudah terbentuk maka bila anak bermain media digital anak akan memprioritaskan terlebih dahulu tanggung jawabnya. 13) Lakukan pencegahan dan kontrol. Dengan cara berdiskusi tentang teknologi saat ini dan manfaat utama dari 
teknologi tersebut. Diskusi dapat menjembatani anak dengan orang tua agar orang tua tidak seolah-olah menggurui anaknya.

\section{SIMPULAN}

Peran ibu sebagai madrasah pertama dan utama di Kota Bandung, berada dalam jalur yang sesuai. Masih banyaknya seorang ibu yang mengurus dan mendidik anaknya seorang diri dengan memberikan pendidikan yang sesuai dengan proses perkembangannya. Walaupun adanya ibu yang melakukan pekerjaan di luar rumah tetapi proses pendidikan masih dapat dipegang oleh orang tua sendiri tanpa dilimpahkan sepenuhnya kepada pihak lain dan proses pendidkan yang diberikan sesuai dengan daya berfikir dan tahap perkembangan.

Pesatnya perkembangan teknologi digital juga sudah lumrah diketahui oleh seluruh ibu. Ibu sebagai sosok madrasah pertama dan utama bagi anak sudah memahami secara umum dampak negatif dan positif dari perkembangan teknologi digital di era 4.0 ini. Dilihat dari data angket yang telah kami kumpulkan. Para ibu sebenarnya telah mengetahui dampak era revolusi industri dari pengaruh negatif hingga pengaruh positif bagi anak. Mereka menyetujui adanya pengarahan dalam hal tujuan hidup anak, kontroling dalam penggunaan media digital, dan menjelaskan pada anak arti kebebasan postif pada era 4.0. Oleh sebab itu ibu sebagai madrasah pertama bagi anak sangat diperlukan.

\section{DAFTAR PUSTAKA}

Abdullah, F. (2019). Fenomena Digital. Jurnal Dimensi DKV Seni Rupa dan Desain, 4, 47-58. https://doi.org/http://dx.doi.org/10.2 5105/jdd.v4i1.4560.

Astuti, Arifian Dwi, dkk. (2020). Menerapkan Sikap dan Perilaku yang Berprinsip pada Bhinneka Tunggal Ika di Era 4.0 dalam Pembelajaran K13 di MI/SD Kelas IV. JMIE: Journal of Madrasah Ibtidaiyah Education,4(1), 86-99. jmie.v4i1.173.

BPS Provinsi Jawa Barat (2018). https://bandungkota.bps.go.id/staticta ble/2018/07/05/143/jumlahpenduduk-usia-kerja-menurutkegiatannya-di-kotabandung-tahun2015---2017.html.

Creswell, J. W. (2010). Research Design: Pendekatan Kualitatif, Kuantitatif, dan Mixed. Yogjakarta: PT Pustaka Pelajar

Gade, F. (2012). Ibu Sebagai Madrasah Dalam Pendidikan Anak. Jurnal Ilmiah Didaktika, vol 13(1), 31-40. https://doi.org/10.22373/jid.v13i1.462.

Hartini. (2011). Metodologi Pendidikan Anak Dalam Pandangan Islam (Studi Tentang Cara Cara Rasulullah Saw. Dalam Mendidik Anak). Jurnal Pendidikan Indonesia, vol 139(1), 3143. 
Kartono, K. (2000). Hygiene Mental. Jakarta : CV. Mandar Maju.

Kementerian Pendidikan dan Kebudayaan (2019). Mendidik Anak Di Era Digital. ://sahabatkeluarga.kemdikbud.go. id/laman/uploads/Dokumen/6951_20 1909-05/4. Modul Mendidik Anak di Era Digital.pdf.

Mahrus, M. (2018). Model Pendidikan Agama Anak bagi Wanita Karir Keluarga Muslim di Kota Malang. Journal PIWULANG, vol 1 . https:// doi.org/10.32478/ngulang.v1i1.153

Martalisa, W. \& Budisetyani, W. (2013). Hubungan Intensitas Keikutsertaan Hypnobirthing dengan Tingkat Kecemasan Ibu Hamil di Gianyar. Jurnal Psikologi Udayana. Vol. 1 (1) 116-128. DOI : https://doi.org/10.24843/JPU.2013.v01.i01.p12

Mastiyah, I. (2017). Pendidikan Anak Usia Dini menurut Islam. EDUKASI: Jurnal Penelitian Pendidikan Agama Dan Keagamaan, 5(3), 187-198. https://doi.org/10.32729/edukasi.v5i3.138.

Nahriyah, S. (2017). Tumbuh kembang anak di era digital. Risalab, Jurnal Pendidikan Dan Studi Islam, vol 4(1), 65-74. https://doi.org/10.5281/zenodo.1227 474.

Nurhayati, \& Syahrizal. (2015). Urgensi dan Peran Ibu Sebagai Madrasah Al- Ula dalam Pendidikan Anak. Itqan, vol 6(2), 153-167.

Parhan, M. \& Sutedja, B. (2019). Penerapan Pendekatan Pembelajaran Kontekstual dalam Pendidikan Agama Islam Di Universitas Pendidikan Indonesia. TARBAWY: Indonesian Journal of Islamic Education. vol 6(2), 114-126. https://doi.org/10.17509/t.v6vi2.20165

Parhan, M., Faiz, A., Karim, A., Nugraha, R. H., Subakti, G. E., Rindu, M., Islamy, F., Budiyanti, N., Fuadin, A., \& Tantowi, Y. A. (2020). Internalization Values of Islamic Education at University. International Journal of Psychosocial Rehabilitation, vol 24(8), 1477814791. https://doi.org/10.37200/IJPR/V24I8/PR281455

Poerwadarminta, W.J.S. (2002). Kamus Umum Bahasa Indonesia. Balai Pustaka. Jakarta.

Prasetiantono, A. T. (2018). Revolusi Industri 4.0: Analisis Ekonomi. Harian Kompas, Selasa, 10 April 2018.

Rahmat, S. T. (2018). Pola Asuh yang Efektif untuk Mendidik Anak di Era Digital. Jurnal Pendidikan dan Kebudayaan Missio, Vol 10 (2). 137-273.

Ratnaya, I. G. (2011). Dampak Negatif Perkembangan Teknologi Informatika dan Komunikasi Dan Cara Antisifasinya. Jurnal Pendidikan Teknologi dan Kejuruan, vol 8(1), 17-28. https://doi.org/10.23887/jptk.v8i1.28 90.

Rosyad, A. M. \& Zuchdi, D. (2018) Aktualisasi Pendidikan Karakter Berbasis Kultur Sekolah dalam Pembelajaran IPS di SMP. Harmoni Sosial: Jurnal Pendidikan IPS. Volume 5 (1). 7992. DOI: https://doi.org/10.21831/hsjpi.v5i1.14925 
Santosa, S. (2015). Karakteristik anak 4.0. Jakarta : PT.Alex Media.

Sarafuddin \& Jumanto. (2016). Peran ibu dalam pendidikan keluarga untuk mendukung keberhasilan pendidikan formal anak di Sekolah Dasar (studi Kasus di Kelurahan Gilingan). Jurnal Profesi Pendidik. Vol 3 (1). 44-57.

Subakti, Y. \& Anggrani, D. R. (2007). Ensiklopedia Calon Ibu: Panduan Lengkap Mendidik Anak Secara Islami (M. Esfand (ed.). QultumMedia. https://books.google.co.id/books

Sudirjo, E. (2016). Model Pembelajaran Inovatif Berbasis Konsep Sekolah Ramah Anak. Edu Humaniora. Jurnal Pendidikan Dasar Kampus Cibiru, vol 2(1). https://doi.org/10.17509/eh.v2i1.2748

Sukiman, R. (2016). Mendidik Anak di Era Digital. Seri Pendidikan Orang Tua.

Trianingsih, R. (2016). Pengantar Praktik Mendidik Anak Usia Sekolah Dasar. Al Ibtida, Vol. 3 No. 2. 197-211. DOI: 10.24235/al.ibtida.snj.v3i2.880

Zarman, W. (2011). Ternyata Mendidik Anak Cara Rasulullah Itu Mudah \& Efektif (Ade Saeful Muslim (ed.). Penerbit Ruang Kata. https://books.google.co.id/books?id= 9ZUvdZntBvMC\&lpg=PP1\&hl=id\&p $\mathrm{g}=\mathrm{PP} 1 \#_{\mathrm{v}}=$ onepage\&q\&f=false. 